\title{
Article \\ Cardiorespiratory Fitness Predicted by Fibrinogen and Leptin Concentrations in Children with Obesity and Risk for Diabetes: A Cross-Sectional Study and a ROC Curve Analysis
}

\author{
Kyriaki Tsiroukidou ${ }^{1, *}$, Elpis Hatziagorou ${ }^{1}$, Maria G. Grammatikopoulou ${ }^{1,2}\left(\mathbb{D}\right.$, Anastasios Vamvakis ${ }^{1, *(1)}$, \\ Kalliopi Kontouli ${ }^{1}$, Christos Tzimos ${ }^{3}{ }^{1}$, John Tsanakas ${ }^{1}$ and Bessie E. Spiliotis ${ }^{4}$ \\ 1 3rd Department of Pediatrics, Hippokration General Hospital, 49 Konstantinoupoleos Str, Aristotle \\ University of Thessaloniki, GR-54642 Thessaloniki, Greece; hatziagorou@auth.gr (E.H.); \\ mariagram@auth.gr (M.G.G.); kkontoul@otenet.gr (K.K.); tsanakasj@gmail.com (J.T.) \\ 2 Department of Nutritional Sciences \& Dietetics, Faculty of Health Sciences, International Hellenic University, \\ Alexander Campus, Sindos, P.O. Box 141, GR-57400 Thessaloniki, Greece \\ 3 Northern Greece Statistics Directorate, Hellenic Statistical Authority, GR-54646 Thessaloniki, Greece; \\ ctzimos@gmail.com \\ 4 Paediatric Endocrine Research Laboratory, Division of Paediatric Endocrinology and Diabetes, Department of \\ Paediatrics, School of Medicine, University of Patras, University Campus, GR-26504 Patras, Greece; \\ besspil@endo.gr \\ check for
} updates

Citation: Tsiroukidou, K.; Hatziagorou, E.; Grammatikopoulou, M.G.; Vamvakis, A.; Kontouli, K.; Tzimos, C.; Tsanakas, J.; Spiliotis, B.E. Cardiorespiratory Fitness Predicted by Fibrinogen and Leptin Concentrations in Children with Obesity and Risk for Diabetes: A Cross-Sectional Study and a ROC Curve Analysis. Nutrients 2021, 13, 674. https://doi.org/ 10.3390/nu13020674

Academic Editor: Sara Baldassano

Received: 29 December 2020

Accepted: 12 February 2021

Published: 19 February 2021

Publisher's Note: MDPI stays neutral with regard to jurisdictional claims in published maps and institutional affiliations.

Copyright: () 2021 by the authors. Licensee MDPI, Basel, Switzerland. This article is an open access article distributed under the terms and conditions of the Creative Commons Attribution (CC BY) license (https:// creativecommons.org/licenses/by/ $4.0 /)$.
Abstract: Obesity is defined as abnormal or excessive fat accumulation that presents a risk to health. The ability to exercise is affected by adiposity, and this mechanism involves low-grade chronic inflammation and homeostatic stress produced mainly in adipocytes, which can result in abnormal adipokine secretion. To date, the gold standard for cardiorespiratory fitness assessment is considered to be the maximum oxygen uptake $\left(\mathrm{VO}_{2 \mathrm{max}}\right)$. The aim of the present study was to assess the prognostic value of hematological parameters of childhood obesity, as potential predictors of cardiorespiratory fitness $\left(\mathrm{VO}_{2 \mathrm{max}}\right)$, using a sample of children and adolescents with obesity and risk for diabetes. A total of 84 clinically healthy children and adolescents were recruited, of which 21 were considered lean, 22 overweight and 41 obese, with a mean age of $12.0 \pm 1.9,11.4 \pm 2.0$, and $11.2 \pm 2.1$ years old, in each weight status category, respectively. Age and sex did not differ between groups. Hematologic testing was performed after $12 \mathrm{~h}$ of fasting including glucose, serum lipids, insulin, hc-CRP, adiponectin, leptin and fibrinogen levels. Cardiorespiratory capacity for exercise was assessed to determine $\mathrm{VO}_{2 \max }$, using a cycle ergometer. The $\mathrm{VO}_{2 \max }$ was negatively correlated with progressive strength to the BMIz $(-0.656, p \leq 0.001)$, hs-CRP $(\mathrm{r}=-0.341, p \leq 0.002)$, glucose $(\mathrm{r}=-0.404, p \leq 0.001)$ and insulin levels $(\mathrm{r}=-0.348, p \leq 0.001)$, the homeostasis model assessment of insulin resistance (HOMA-IR) $(\mathrm{r}=-0.345, p \leq 0.002)$, as well as to the leptin $(\mathrm{r}=-0.639, p \leq 0.001)$ and fibrinogen concentrations $(\mathrm{r}=-0.520, p \leq 0.001)$. The multivariate analysis revealed that only leptin and fibrinogen concentrations could predict the $\mathrm{VO}_{2 \max }$ adjusted for the $\mathrm{BMIz}$ of participants. The receiver operating characteristic (ROC) curve for the diagnostic accuracy of leptin, hs-CRP and fibrinogen concentrations for the prediction of $\mathrm{VO}_{2 \max }$ revealed a good diagnostic ability for all parameters, with leptin being the most promising one (area under the curve (AUC): 99\%). The results verify that in children with obesity, $\mathrm{VO}_{2 \max }$ may be predicted from hematological parameters (leptin and fibrinogen), possibly bypassing more invasive methods.

Keywords: obese; overweight; childhood; cardiopulmonary test; insulin resistance; CPET; adiposity; $\mathrm{VO}_{2 \mathrm{max}}$; high-sensitive CRP; nutrition; exercise; metabolic health

\section{Introduction}

Obesity is the result of a positive energy balance and/or physical inactivity, demonstrated by excessive body weight deposition for one's height. The pathophysiology of 
obesity is complex and multifactorial, with the initial trigger stemming from homeostatic stress produced mainly in adipocytes, resulting in adipokine secretion attempting to balance energy homeostasis $[1,2]$. As a result, leptin levels are increased during obesity, with a parallel reduction in circulating adiponectin [3-5]. In parallel, variants of the adipokineencoding genes are also affected [6], all adding to an increased risk for the development of diabetes.

Moreover, obesity is associated with a plethora of coagulation factors, all setting the basis for the establishment of the atherosclerotic process and cardiovascular disease (CVD) [7-9]. Of these, fibrinogen, a hemostatic protein produced by the hepatocytes, acts early on during the beginning of the atherothrombotic procedure [10,11]. Elevated fibrinogen concentrations have been reported in obese children and can serve as a prodromal atherosclerosis proxy index, for early intervention $[8,12,13]$.

One of the most important results of obesity is the reduced cardiorespiratory fitness (CRF) observed due to exercise intolerance [14,15]. This phenomenon is in fact multifactorial, influenced by the hormonal background, the lack of motivation and engagement in physical activity (PA) compared to children with normal weight, as well as to the difficulty experienced in moving one's body during exercise, further reducing CRF [14]. To date, the gold standard for CRF assessment is considered to be maximum oxygen uptake $\left(\mathrm{VO}_{2 \max }\right)[14,16]$. Overall, $\mathrm{VO}_{2 \max }$ is a difficult procedure for children, who often fail to achieve the reported standards $[14,17,18]$, resulting in limited available data to date. On the other hand, $\mathrm{VO}_{2 \max }$ is influenced by both the genotype [19] and the phenotype, with obesity and insulin resistance being important CRF effectors [20]. In parallel, research has suggested that, through ameliorating CRF, we could attenuate the adverse events of obesity in children, by mediating the cardiometabolic risk and insulin resistance, hence delaying the progression to type 2 diabetes mellitus [21,22].

Studies have revealed a decreased CRF with increasing leptin and fibrinogen concentrations among children and adolescents [23-27] and a linear relationship between adiponectin and CRF [28]. With adipokines being influenced by physical activity [24] and vice versa [29], understanding their role is pivotal in exercise recommendations and primary and secondary prevention of obesity. Additionally, considering the difficulty in assessing $\mathrm{VO}_{2 \max }$ among children with obesity and risk for diabetes, it would be extremely useful if it could be predicted by more assessable indicators.

The aim of the present case-control study was to determine $\mathrm{VO}_{2 \max }$ levels among children of different weight status tiers and evaluate possible correlations between $\mathrm{VO}_{2 \max }$, serum leptin, adiponectin and fibrinogen levels.

\section{Materials and Methods}

\subsection{Participant Recruitment and Inclusion Criteria}

A total of 63 children and adolescents, 22 overweight and 41 with obesity (Table 1), aged 8-16 years old were recruited from the Endocrine outpatient Clinic of the 3rd Department of Pediatrics, of the Hippokration University Hospital, in Thessaloniki, Greece. Participants had scheduled appointments for overweight/obesity evaluation. Lean children and adolescents $(n=21)$ were recruited from local schools, via advertisements, forming the control group. Thus, the number of participants totaled 84 children and adolescents, who were divided into three groups, according to body weight status. Participant characteristics are presented in Table 1. Exclusion criteria included a diagnosis of (1) chronic diseases; (2) mental retardation; (3) failure to perform the cardiopulmonary exercise test; (4) young age of participants (below 8 years old); (5) posture difficulties affecting the ability to perform the CRF test; (6) inability to fulfill the prerequisite criteria for the $\mathrm{VO}_{2 \max }$ tests; (7) use of any medication. 
Table 1. Participant characteristics (mean $\pm \operatorname{SD}$ or $n$ ).

\begin{tabular}{cc}
\hline Age (years) & $11.5 \pm 2.0$ \\
Sex (boys/girls) $(n)$ & $42 / 42$ \\
Prepubertal/pubertal $(n)$ & $26 / 58$ \\
BMIz & $2.26 \pm 1.46$ \\
Weight status (normoweight/overweight/obese) $(n)$ & $21 / 22 / 41$ \\
\hline BMIz: body mass index z-score [30,31]; SD: standard deviation.
\end{tabular}

\subsection{Ethical Permission and Consent}

Parents/guardians of participants signed informed consent forms prior to participation, after having the aims and method of the study explained in full detail. The protocol was approved by the Bioethics Committee of the Medical School of Aristotle University of Thessaloniki (Ref No. 91/21-12-2009). All data were handled with emphasis on anonymity and data protection, according to the Declaration of Helsinki and its latter amendments. This is a secondary analysis of a previous reported sample [26], with the use of a universally accepted weight status classification, inclusion criteria and participant categorization.

\subsection{Anthropometric Indices}

Body weight and height of participants were measured at approximately 9:00 a.m. by an experienced pediatrician (K.T.) and a dietitian (A.V.) using a Harpenden wall-mounted stadiometer (Holtain Ltd., Crymych, UK) and a Seca 700 mechanical column scale (Seca, Hamburg, Germany).

Body mass index (BMI) was calculated as the ratio of body mass $(\mathrm{kg})$, towards the height of each participant, squared $\left(\mathrm{m}^{2}\right)$. Weight status was defined according to the World Health Organization (WHO) international growth reference data for children and adolescents $>5$ years of age [30,31]. WHO Anthro software [32] was used to calculate the BMI z-scores (BMIz). Overweight and obesity were identified in children with a BMIz $>1$ standard deviation (SD) and BMIz >2SD, respectively [33].

Waist circumference was recorded using an anelastic measuring tape, with participants in the horizontal plane, midway between lower margin of the last palpable rib and the iliac crest [34], according to the WHO STEPS (STEPwise Approach to Surveillance) protocol [35]. Hips perimeter was measured at the widest portion of the buttocks [34], and waist/hip ratio was calculated accordingly.

\subsection{Puberty Staging}

Stage of sexual maturation was assessed by an experienced pediatric endocrinologist (K.T.), based on the Tanner stages criteria [36]. According to the sexual maturity rating, participants at stage 1 were considered as prepubertal, and all other stages were indicative of puberty.

\subsection{Cardio-Pulmonary Exercise Test (CPET)}

CRF was assessed with a cardio-pulmonary exercise test (CPET), performed on a cycle ergometer (Egromedic 828E, Monark Exercise, Vansbro, Sweden) using a spirometer (Sensormedics, Flowsensor, VMAX SERIES, v.20-1, Loma Linda, CA, USA) [14]. The test procedure was explained in detail to both the children and their guardians, and the first also had the opportunity to familiarize themselves with the cycle ergometer prior to the measurements.

The exercise protocol began with a resting period of $2 \mathrm{~min}$ for baseline measurements, followed by a $3 \mathrm{~min}$ warm-up period of unloaded cycling power. Exercise challenge consisted of progressively increasing increments of $10 \mathrm{Watt} / \mathrm{min}$, followed by a recovery stage lasting for $3 \mathrm{~min}$. All children were encouraged to exercise until the onset of exhaustion, throughout the test. 


\subsection{Blood and Biochemical Assays}

Fasting venous blood was obtained from all participants at 9:00 a.m. and either assessed, or immediately centrifuged with the serum being stored at $-80^{\circ} \mathrm{C}$. Stored serum samples were used for the analyses of triglycerides (TG) and high-density lipoprotein cholesterol (HDLC) levels, using Vitro Chemistry DT60 (Johnson \& Johnson, NY, USA). Fasting blood glucose (FBG) levels were assessed with the hexokinase method (AU 2700 Analyzer, Beckman Coulter Inc., Orange County, CA, USA).

Citrated plasma samples were used for the assay of fibrinogen levels, using a commercially available kit (Multifriben U, SIEMENS), based on the Geftkin et al. [37] method.

Insulin levels were assessed using a Human Insulin ELISA kit (ALPCO Diagnostics) with both inter- and intra-assay precision being below 15\%. The HOMA-IR (homeostasis model assessment of insulin resistance) was calculated by (fasting insulin $(\mu \mathrm{U} / \mathrm{mL}) \times$ fasting glucose $(\mathrm{mM}) / 22.5)$ for insulin resistance [38].

Serum leptin and adiponectin levels were assessed with Human Leptin ELISA kits (Diagnostic Systems Laboratories, Texas, USA and AdipoGen, Seoul, Korea, respectively). The intra-assay coefficient of variation $(\mathrm{CV})$ for adiponectin was $2.97-3.84 \%$ and the reported inter-assay ranging between 2.84 and $5.5 \%$. The respective intra- and inter-assay CVs for leptin were 5.9 and 5.6\%, respectively. High-sensitivity C-reactive protein (hs-CRP) was determined by a two-site chemiluminescent enzyme assay.

\subsection{Statistical Analyses}

All analyses were carried out with the Jamovi v. 1.2 (the Jamovi project) using the $R$ language, and the SPSS statistical software v. 23.0 (IBM, Chicago, IL, USA). The level of significance was set at $5 \%$. Initially, the general characteristics of variables were examined and, thereafter, we assessed all prerequisites for performing statistical analyses, including normality in distribution, variations, etc. Due to the uneven number of participants in each group, the bootstrap technique was applied for 10,000 identical items.

Differences between groups were assessed with ANOVA, using Bonferroni correction for normally distributed continuous variables. Such variables are presented as mean \pm standard deviations (SD). For categorical variables, differences between groups were assessed with the Chi-square test. Correlations between variables were evaluated with the Pearson's test.

Apart from crude parameters, the $\mathrm{VO}_{2 \max }$ was also adjusted to the BMIz of each participant and the calculated adjusted values were also used in the analyses.

For the assessment of the diagnostic ability of leptin, hs-CRP and fibrinogen in predicting $\mathrm{VO}_{2 \max }$, receiver operating characteristic (ROC) curves were also plotted [39].

Univariate and multivariate regression models were also designed, using quantitative variables. The effect of the degree of obesity in CRF was assessed with general linear models. Degree of obesity was converted to a dummy variable for use in multiple regression models, in order to better define the best model explaining the results, using stepwise and enter methods. Residual distribution was assessed in all cases, using the Kolmogorov-Smirnov test. Models were also assessed for tolerance and collinearity.

\section{Results}

\subsection{Differences in Anthropometry, Hormonal Levels and CRF}

Table 2 details between-group differences in the anthropometric, exercise and biochemical characteristics of participants. As expected, anthropometric indices were different between groups, with obese participants demonstrating greater BMI, BMIz, waist and hips circumferences, as well as waist/hips ratio. HOMA-IR and leptin levels were significantly lower among lean controls, compared to the obese, but in contrast, $\mathrm{VO}_{2 \max }$ was significantly higher. Overall, $\mathrm{VO}_{2 \max }$ was significantly reduced at each increasing obesity tier. In parallel, leptin and fibrinogen levels were significantly increased at each higher adiposity level. The results remained similar for all of the aforementioned parameters, even after dividing the sample according to sex, with the exception of fibrinogen levels. 
Table 2. Anthropometric, biochemical and exercise test parameters of participants according to sex and weight status (mean \pm SD).

\begin{tabular}{|c|c|c|c|c|c|c|c|c|c|c|}
\hline \multirow[b]{2}{*}{ Characteristics } & \multicolumn{3}{|c|}{ Normoweight } & \multicolumn{3}{|c|}{ Overweight } & \multicolumn{3}{|c|}{ Obese } & \multirow{2}{*}{$\begin{array}{c}p \text {-Value between Weigh } \\
\text { Status Tiers }\end{array}$} \\
\hline & $\begin{array}{l}\text { Boys } \\
(n=9)\end{array}$ & $\begin{array}{c}\text { Girls } \\
(n=12)\end{array}$ & $\begin{array}{c}\text { Total } \\
(n=21)\end{array}$ & $\begin{array}{c}\text { Boys } \\
(n=9)\end{array}$ & $\begin{array}{c}\text { Girls } \\
(n=13)\end{array}$ & $\begin{array}{c}\text { Total } \\
(n=22)\end{array}$ & $\begin{array}{c}\text { Boys } \\
(n=24)\end{array}$ & $\begin{array}{c}\text { Girls } \\
(n=17)\end{array}$ & $\begin{array}{c}\text { Total } \\
(n=41)\end{array}$ & \\
\hline Age (years) & $12.3 \pm 2.2$ & $11.9 \pm 1.7$ & $12.0 \pm 1.9$ & $12.0 \pm 1.8$ & $10.9 \pm 2.1$ & $11.4 \pm 2.0$ & $11.3 \pm 2.3$ & $11.1 \pm 1.9$ & $11.2 \pm 2.1$ & NS \\
\hline Prepubertal/pubertal $(n)$ & $4 / 5$ & $1 / 11$ & $5 / 16$ & $2 / 7$ & $3 / 10$ & $5 / 17$ & 13/11 & $3 / 14$ & $16 / 25$ & NS \\
\hline Body weight $(\mathrm{kg})$ & $45.2 \pm 13.9$ & $41.2 \pm 11.6^{\ddagger}$ & $42.8 \pm 12.3$ 执 & $57.7 \pm 13.3$ & $55.9 \pm 9.9^{*}$ & $56.6 \pm 11.2$ 抹 & $71.2 \pm 24.3^{*}$ & $69.9 \pm 14.0^{* * *}$ & $70.6 \pm 20.5$ & $<0.001$ \\
\hline Height $(\mathrm{m})$ & $1.53 \pm 0.16$ & $1.48 \pm 0.13$ & $1.50 \pm 0.14$ & $1.55 \pm 0.17$ & $1.49 \pm 0.1$ & $1.52 \pm 0.13$ & $1.5 \pm 0.12$ & $1.5 \pm 0.1$ & $1.51 \pm 0.11$ & NS \\
\hline $\operatorname{BMI}\left(\mathrm{kg} / \mathrm{m}^{2}\right)$ & $18.8 \pm 2.4$ fł‡ & $18.3 \pm 2.6$ 执 & $18.5 \pm 2.5$ 执 & $23.7 \pm 1.0$ ** & $24.9 \pm 1.7^{* * *}$ & $24.4 \pm 1.6^{\ddagger \neq \ddagger * * *}$ & $30.0 \pm 3.2^{* * *}$ & $29.6 \pm 3.3^{* * *}$ & $29.8 \pm 3.22$ & $<0.001$ \\
\hline BMIz & $0.4 \pm 0.62$ 执 & $0.03 \pm 1.02 \ddagger$ & $0.18 \pm 0.88$ 抽 & $2.03 \pm 0.48^{* * *}$ & $2.24 \pm 0.4^{* * *}$ & $2.15 \pm 0.43$ & $3.57 \pm 0.77^{* * *}$ & $2.98 \pm 0.56^{* * *}$ & $3.33 \pm 0.74$ & $<0.001$ \\
\hline Waist circumference $(\mathrm{cm})$ & $64 \pm 9.7 \ddagger$ & $64.4 \pm 8.1^{\ddagger}$ & $64.2 \pm 8.6$ 执 & $84.6 \pm 4.7^{*}$ & $86.6 \pm 9.3^{* * *}$ & 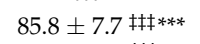 & $100.3 \pm 17.7^{* * *}$ & $100.4 \pm 12.4^{* * *}$ & $100.33 \pm 15.53$ & $<0.001$ \\
\hline Hips circumference $(\mathrm{cm})$ & $78.1 \pm 10.3$ & $81.0 \pm 9.3 \ddagger$ & $79.7 \pm 9.6$ 执 & $91.3 \pm 8.5$ & $94.3 \pm 8.9 * *$ & 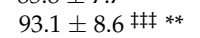 & $101.3 \pm 13.9^{* * *}$ & $103.1 \pm 7.8^{* * *}$ & $102.05 \pm 11.67$ & $<0.001$ \\
\hline Waist/hips ratio & $0.82 \pm 0.02$ & $0.8 \pm 0.05$ & $0.81 \pm 0.04$ 执 & $0.93 \pm 0.06 * *$ & $0.92 \pm 0.04 * * *$ & $0.92 \pm 0.05$ 执** & $0.99 \pm 0.08^{* * *}$ & $0.97 \pm 0.08^{* * *}$ & $0.98 \pm 0.08$ & $<0.001$ \\
\hline hs-CRP (mg/dL) & $0.13 \pm 0.09$ & $0.14 \pm 0.09$ & $0.13 \pm 0.09$ & $0.23 \pm 0.16$ & $0.28 \pm 0.27$ & $0.26 \pm 0.23$ & $0.78 \pm 1.32$ & $0.39 \pm 0.33$ & $0.62 \pm 1.04$ & 0.040 \\
\hline Glucose (mg/dL) & $75.7 \pm 7.0$ & $82.4 \pm 6.4$ & $79.5 \pm 7.3$ 执 & $84.2 \pm 7.5$ & $84.3 \pm 8.1$ & $84.3 \pm 7.6$ & $88.5 \pm 7.8^{* * *}$ & $87.5 \pm 6.0$ & $88.1 \pm 7.03$ & $<0.001$ \\
\hline Insulin ( $\mu \mathrm{UI} / \mathrm{mL})$ & $2.6 \pm 1.5$ & $3.1 \pm 2.4$ & $2.9 \pm 2.1$ 执 & $5.6 \pm 4.8$ & $7.4 \pm 5.1$ & $6.6 \pm 4.9$ & $13.5 \pm 17.1$ & $12.4 \pm 8.0^{* * *}$ & $13.07 \pm 13.93$ & 0.001 \\
\hline $\mathrm{TG} / \mathrm{HDL}$ & $0.9 \pm 0.5$ & $1.3 \pm 0.5$ & $1.1 \pm 0.5$ 㧊 & $1.8 \pm 1.1$ & $2.1 \pm 1.3$ & $1.9 \pm 1.2$ & $2.0 \pm 1.3^{*}$ & $2.3 \pm 1.4$ & $2.13 \pm 1.31$ & 0.006 \\
\hline HOMA-IR & $0.5 \pm 0.3$ & $0.6 \pm 0.5$ & $0.6 \pm 0.4$ 㧊 & $1.2 \pm 1.2$ & $1.6 \pm 1.2$ & $1.4 \pm 1.2$ & $3.1 \pm 4.2$ & $2.7 \pm 1.7^{* * *}$ & $2.92 \pm 3.34$ & 0.001 \\
\hline $\mathrm{VO}_{2 \max }(\mathrm{mL} / \mathrm{kg} / \mathrm{min})$ & $48.3 \pm 6.9 \ddagger$ & $46.4 \pm 7.6$ & $48.7 \pm 6.2$ 执 & $38.1 \pm 6.7^{* *}$ & $33.6 \pm 5.0^{* * *}$ & $35.7 \pm 6.0^{* * * \neq \pm \ddagger}$ & $31.5 \pm 5.9^{* * *}$ & $28.4 \pm 5.3^{* * *}$ & $30.38 \pm 5.95$ & $<0.001$ \\
\hline $\mathrm{VO}_{2 \max }(\%)$ & $95.7 \pm 8.2 \ddagger$ & $107.5 \pm 15.4$ & $102.9 \pm 14.1^{\text {执 }}$ & $74.1 \pm 14.0$ ** & $74.9 \pm 11.1^{* * *}$ & $75.1 \pm 12.1$ & $58.5 \pm 11.1 * * *$ & $65 \pm 11.8^{* * *}$ & $61.32 \pm 11.74$ & $<0.001$ \\
\hline Leptin (ng/mL) & $4.0 \pm 3.2 \ddagger$ & $6.5 \pm 3.5$ & $5.5 \pm 3.5$ 执 & $21.9 \pm 12.7^{*}$ & $30 \pm 9.3^{* * *}$ & $\underset{* * * \neq \neq \ddagger}{25.5 \pm 11.8}$ & $37.1 \pm 16.0 * * *$ & $42.5 \pm 20.7^{* * *}$ & $39.65 \pm 18.98$ & $<0.001$ \\
\hline Adiponectin $(\mu \mathrm{g} / \mathrm{mL})$ & $15.8 \pm 6.5$ & $14.9 \pm 6.8$ & $15.3 \pm 6.5$ & $14.5 \pm 5.2$ & $14.9 \pm 9.2$ & $14.7 \pm 7.5$ & $13.1 \pm 5.7$ & $10.5 \pm 3.9$ & $12.06 \pm 5.15$ & NS \\
\hline Fibrinogen $(\mathrm{mg} / \mathrm{dL})$ & $235.6 \pm 68.8$ & $253.5 \pm 69.3$ & $245.0 \pm 67.8$ 执 & $324.2 \pm 61.7^{*}$ & $302.4 \pm 87.9$ & $311.0 \pm 77.4 * \neq \ddagger$ & $373.4 \pm 61.2 * * *$ & $384.4 \pm 99.5^{* * *}$ & $378.0 \pm 78.4$ & 0.001 \\
\hline
\end{tabular}

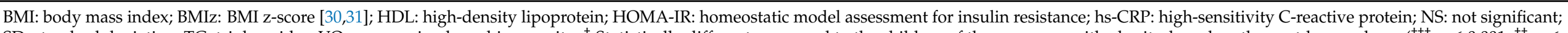

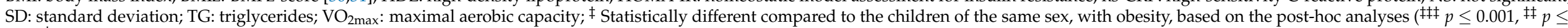

$0.01, \neq p<0.05) ;{ }^{*}$ statistically different compared to the normoweight children of the same sex, based on post-hoc analyses $(* * * p \leq 0.001, * * p \leq 0.01, * p<0.05)$. 
In Table 3, differences in the anthropometric, CRF and biochemical characteristics of participants are presented according to puberty and weight status. With regard to the anthropometric indices, all were significantly increased with each ascending weight status tier, in both prepubertal and pubertal children. Irrespective of puberty status, $\mathrm{VO}_{2 \max }$ was decreased in each ascending adiposity level, whereas circulating leptin and fibrinogen levels were increased, in parallel to the weight status.

Table 3. Anthropometric, biochemical and exercise test parameters of participants according to puberty stage and weight status (mean $\pm \mathrm{SD}$ ).

\begin{tabular}{|c|c|c|c|c|c|c|}
\hline \multirow[b]{2}{*}{ Characteristics } & \multicolumn{3}{|c|}{ Prepubertal } & \multicolumn{3}{|c|}{ Pubertal } \\
\hline & $\begin{array}{c}\text { Normoweight } \\
\quad(n=5)\end{array}$ & $\begin{array}{l}\text { Overweight } \\
\quad(n=5)\end{array}$ & $\begin{array}{c}\text { Obese } \\
(n=16)\end{array}$ & $\begin{array}{l}\text { Normoweight } \\
\quad(n=16)\end{array}$ & $\begin{array}{l}\text { Overweight } \\
\quad(n=17)\end{array}$ & $\begin{array}{c}\text { Obese } \\
(n=25)\end{array}$ \\
\hline Age (years) & $10.3 \pm 1.0$ & $10.0 \pm 1.4$ & $9.6 \pm 1.3$ & $12.6 \pm 1.8$ & $11.8 \pm 2.0$ & $12.2 \pm 1.9$ \\
\hline Boys/girls $(n)$ & $4 / 1$ & $2 / 3$ & $13 / 3$ & $5 / 11$ & $7 / 10$ & $11 / 14$ \\
\hline Body weight (kg) & $33.8 \pm 5.0$ & $46.5 \pm 5.7 \ddagger$ & $58.3 \pm 9.1^{* * *}$ & $45.8 \pm 12.7$ & $59.6 \pm 10.7$ 㧊 & $78.5 \pm 21.9 * * *$ \\
\hline Height (m) & $1.4 \pm 0.07$ & $1.39 \pm 0.1$ & $1.42 \pm 0.06$ & $1.54 \pm 0.14$ & $1.55 \pm 0.13$ & $1.57 \pm 0.1$ \\
\hline $\operatorname{BMI}\left(\mathrm{kg} / \mathrm{m}^{2}\right)$ & $17.1 \pm 1.5$ & $24.1 \pm 1.4^{* * * \neq \ddagger}$ & $28.8 \pm 2.7^{* * *}$ & $19.0 \pm 2.6$ & $24.5 \pm 1.6^{* * * \neq \neq \ddagger}$ & $30.5 \pm 3.4^{* * *}$ \\
\hline BMIz & $0.18 \pm 0.59$ & $2.41 \pm 0.14 * * * \ddagger$ & $3.74 \pm 0.71 * * *$ & $0.18 \pm 0.98$ & $2.08 \pm 0.46^{* * * \pm \neq \ddagger}$ & $3.06 \pm 0.65 * * *$ \\
\hline Waist circumference $(\mathrm{cm})$ & $57.0 \pm 5.3$ & $81.3 \pm 6.8 * *$ & $93.7 \pm 12.3^{* * *}$ & $67.0 \pm 8.0$ & 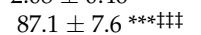 & $104.6 \pm 16.1^{* * *}$ \\
\hline Hips circumference $(\mathrm{cm})$ & $70.2 \pm 4.6$ & $85.9 \pm 5.8 *$ & $94.6 \pm 8.7^{* * *}$ & $83.4 \pm 8.5$ & $95.2 \pm 8.3^{* * \ddagger \ddagger \ddagger}$ & $106.8 \pm 11.0 * * *$ \\
\hline Waist/hips ratio & $0.81 \pm 0.02$ & $0.95 \pm 0.04 * *$ & $0.99 \pm 0.07 * * *$ & $0.8 \pm 0.05$ & $0.9 \pm 0.1 * * * \neq$ & $0.98 \pm 0.08 * * *$ \\
\hline hs-CRP (mg/dL) & $0.18 \pm 0.12$ & $0.31 \pm 0.24$ & $0.69 \pm 1.01$ & $0.12 \pm 0.08$ & $0.24 \pm 0.23$ & $0.58 \pm 1.08$ \\
\hline Glucose (mg/dL) & $76.6 \pm 7.4$ & $85.0 \pm 4.6$ & $86.7 \pm 6.0 *$ & $80.4 \pm 7.3$ & $84.1 \pm 8.4$ & $89.0 \pm 7.57^{* *}$ \\
\hline Insulin $(\mu \mathrm{UI} / \mathrm{mL})$ & $2.0 \pm 0.0$ & $4.1 \pm 4.0$ & $13.1 \pm 19.3$ & $3.1 \pm 2.3$ & $7.2 \pm 5.0 \ddagger$ & $13.1 \pm 9.6^{* * *}$ \\
\hline TG/HDL & $0.7 \pm 0.3$ & $2.5 \pm 1.5$ & $1.8 \pm 1.5$ & $1.3 \pm 0.5$ & $1.8 \pm 1.1$ & $2.3 \pm 1.2 * *$ \\
\hline HOMA-IR & $0.38 \pm 0.04$ & $0.86 \pm 0.89$ & $2.85 \pm 4.42$ & $0.63 \pm 0.48$ & $1.58 \pm 1.22$ & $2.97 \pm 2.52$ \\
\hline $\mathrm{VO}_{2 \max }(\mathrm{mL} / \mathrm{kg} / \mathrm{min})$ & $46.7 \pm 8.4$ & $35.9 \pm 8.2 *$ & $32.2 \pm 6.9^{* *}$ & $47.3 \pm 7.1$ & $35.3 \pm 5.6^{* * * \neq \ddagger}$ & $29.0 \pm 4.8^{* * *}$ \\
\hline $\mathrm{VO}_{2 \max }(\%)$ & $102.7 \pm 21.9$ & $73.4 \pm 10.9$ & $60.7 \pm 13.5^{* * *}$ & $102.9 \pm 13.1$ & $74.9 \pm 12.7^{* * * \neq \ddagger}$ & $61.7 \pm 10.83^{* * *}$ \\
\hline Leptin $(\mathrm{ng} / \mathrm{mL})$ & $4.1 \pm 3.2$ & $27.8 \pm 8.6$ & $38.9 \pm 20.3^{* *}$ & $5.9 \pm 3.6$ & $26.4 \pm 12.2$ ***拉 & $39.6 \pm 17.0 * * *$ \\
\hline Adiponectin $(\mu \mathrm{g} / \mathrm{mL})$ & $18.6 \pm 4.0$ & $18.0 \pm 4.2$ & $13.7 \pm 4.1$ & $14.3 \pm 6.9$ & $14.4 \pm 7.8$ & $11.0 \pm 5.6$ \\
\hline Fibrinogen $(\mathrm{mg} / \mathrm{dL})$ & $244.2 \pm 64.4$ & 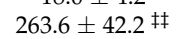 & $367.6 \pm 53.9 * * *$ & $245.9 \pm 71.1$ & $325.3 \pm 80.6 *$ & $384.6 \pm 91.1^{* * *}$ \\
\hline
\end{tabular}

BMI: body mass index; BMIz: BMI z-score [30,31]; HDL: high-density lipoprotein; HOMA-IR: homeostatic model assessment for insulin resistance; hs-CRP: high-sensitivity C-reactive protein; NS: not significant; SD: standard deviation; TG: triglycerides; $\mathrm{VO}_{2 \max }$ : maximal aerobic capacity; ${ }^{\ddagger}$ statistically different compared to the children of the puberty category, with obesity, based on the post-hoc analyses ( ${ }^{\ddagger \ddagger \ddagger}$ $p \leq 0.001, \neq \ddagger p \leq 0.01, \ddagger p<0.05) ;{ }^{*}$ statistically different compared to the normoweight children of the puberty category, based on post-hoc analyses $\left({ }^{* * *} p \leq 0.001, * * p \leq 0.01, * p<0.05\right)$.

\subsection{Correlations between $V \mathrm{O}_{2 \max }$, Anthropometric Parameters and Hormonal Levels}

In the total sample, the crude $\mathrm{VO}_{2 \max }$ (expressed as $\mathrm{mL} / \mathrm{Kg} / \mathrm{min}$ ) demonstrated negative correlations of progressive strength to the BMIz $(-0.656, p \leq 0.001)$, hs-CRP $(\mathrm{r}=-0.341, p \leq 0.002)$, glucose $(\mathrm{r}=-0.404, p \leq 0.001)$ and insulin levels $(\mathrm{r}=-0.348$, $p \leq 0.001)$, HOMA-IR $(\mathrm{r}=-0.345, p \leq 0.002)$, leptin $(\mathrm{r}=-0.639, p \leq 0.001)$ and fibrinogen levels $(\mathrm{r}=-0.520, p \leq 0.001)$ of participating children. On the other hand, a weak, positive correlation was observed with adiponectin $(\mathrm{r}=0.329, p \leq 0.003)$.

When the $\mathrm{VO}_{2 \max }$ was expressed as a percent (\%), all aforementioned correlations either remained similar, or were strengthened, becoming more significant, with the exception of adiponectin $(\mathrm{r}=0.243, p \leq 0.05)$. In more detail, the $\mathrm{VO}_{2 \max }(\%)$ was negatively associated with fibrinogen levels $(\mathrm{r}=-0.530, p \leq 0.001)$, leptin $(\mathrm{r}=-0.624, p \leq 0.001)$, glucose $(\mathrm{r}=-0.365, p \leq 0.001)$ and insulin levels $(\mathrm{r}=-0.419, p \leq 0.001)$, HOMA-IR $(\mathrm{r}=-0.428$, $p \leq 0.002)$, hs-CRP $(\mathrm{r}=-0.380, p \leq 0.001)$, and BMIz $(-0.772, p \leq 0.001)$.

\subsection{Univariate and Multivariate Regression Models Predicting $V \mathrm{O}_{2 \max }$}

Linear correlations with $\mathrm{VO}_{2 \max }$ adjusted for $\mathrm{BMIz}$ and the multivariate regression models predicting $\mathrm{VO}_{2 \max }$ (adjusted) by biochemical parameters, are presented in Table 4 . In the univariate analysis, all variables demonstrated significant correlations with the adjusted $\mathrm{VO}_{2 \max }$. 
Table 4. Linear regression model explaining cardiorespiratory fitness $\left(\mathrm{VO}_{2 \max }\right)$ adjusted for the level of adiposity (BMIz) and biochemical parameters.

\begin{tabular}{|c|c|c|c|c|c|c|}
\hline \multirow[b]{2}{*}{ Variables: } & \multicolumn{3}{|c|}{ Univariate Analysis } & \multicolumn{3}{|c|}{ Multivariate Analysis } \\
\hline & Unadjusted $\beta$ & $95 \% \mathrm{CI}$ & $p$-Value & Adjusted $\beta$ & $95 \% \mathrm{CI}$ & $p$-Value \\
\hline Leptin $(\mathrm{ng} / \mathrm{mL})$ & 0.601 & $\begin{array}{l}(-0.739 \text { to } \\
-0.463)\end{array}$ & $<0.001$ & 0.492 & $\begin{array}{l}(-0.661 \text { to } \\
-0.323)\end{array}$ & $<0.001$ \\
\hline $\begin{array}{c}\text { Fibrinogen } \\
\text { (mg/dL) }\end{array}$ & 0.092 & $\begin{array}{c}(-0.126 \text { to } \\
-0.059)\end{array}$ & $<0.001$ & 0038 & $\begin{array}{c}(-0.074 \text { to } \\
-0.002)\end{array}$ & 0.038 \\
\hline $\begin{array}{l}\text { Adiponectin } \\
(\mu \mathrm{g} / \mathrm{dL})\end{array}$ & 0.665 & $\begin{array}{c}(0.075 \text { to } \\
1.255)\end{array}$ & 0.028 & 0.211 & $\begin{array}{c}(-0.302 \text { to } \\
0.725)\end{array}$ & NS \\
\hline hs-CRP (mg/dL) & 5.938 & $\begin{array}{c}(-10.419 \text { to } \\
-1.457)\end{array}$ & 0.010 & 0.691 & $\begin{array}{c}(-4.889 \text { to } \\
3.508)\end{array}$ & NS \\
\hline
\end{tabular}

BMIz, body mass index z-score [30,31]; CI, confidence intervals; hs-CRP, high-sensitivity C-reactive protein; NS, not significant; $\mathrm{VO}_{2 \max }$, maximal aerobic capacity.

According to the multivariate analysis, only leptin and fibrinogen levels could predict the $\mathrm{VO}_{2 \max }$. The adjusted $\mathrm{R}^{2}$ of the multivariate regression model was equal to 0.527 and although the correlation between leptin and fibrinogen as independent variables was rather strong $(\mathrm{r}=-0.552, p<0.001)$, no collinearity issues existed, as the portion of variance that was not explained by the other variable (tolerance) was greater than 0.73 . In addition, the remaining multicollinearity indicators, including the variance inflation factor (VIF), Eigen values, the condition index and variance proportions, were within the accepted thresholds.

\subsection{Diagnostic Accuracy of Leptin, hs-CRP and Fibrinogen for Predicting $V_{2} O_{2 m a x}$}

The ROC curve for the diagnostic accuracy of leptin, hs-CRP and fibrinogen concentrations for the prediction of $\mathrm{VO}_{2 \max }$ is presented in Figure 1. All parameters had a good diagnostic ability, with leptin being the most promising one. The area under the curve (AUC) of leptin was $99 \%$ with the respective $95 \%$ confidence intervals (CI) between 97.4 and $100 \%$. The AUC of fibrinogen was $85.3 \%$ (95\% CI: 75.5-95.2\%) and that of hs-CRP was estimated at $77.0 \%$ (95\% CI: $66.7-87.3 \%)$.
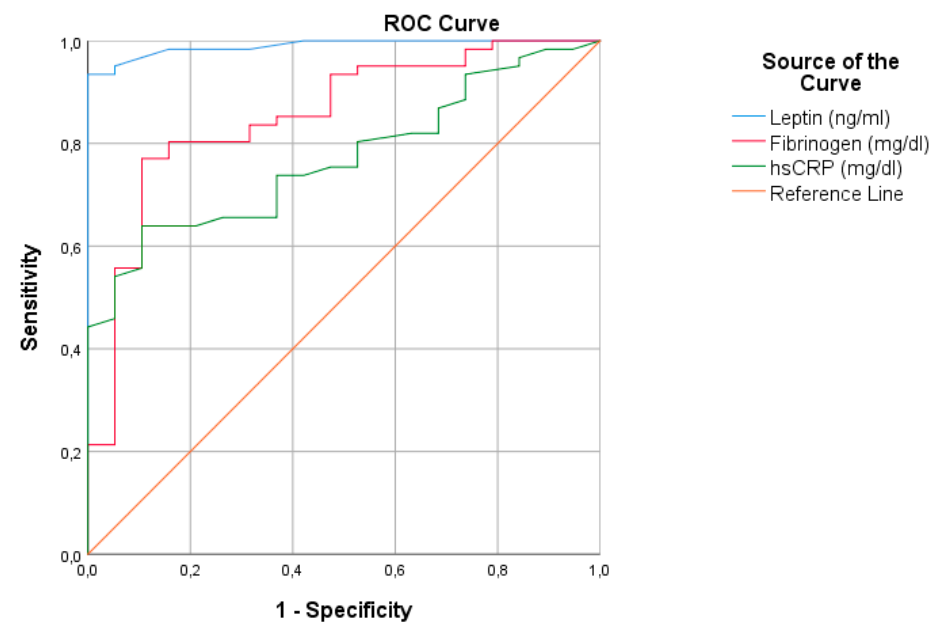

Figure 1. ROC curve of threshold leptin, hs-CRP and fibrinogen levels for predicting $\mathrm{VO}_{2 \max }$ (sensitivity versus specificity). $h s C R P$, high sensitivity $C$-reactive protein; $R O C$, receiver operating characteristic; $\mathrm{VO}_{2 \max }$, maximal aerobic capacity.

\section{Discussion}

Our study revealed that in children with overweight and obesity, leptin and fibrinogen concentrations are strongly correlated to the $\mathrm{VO}_{2 \max }$ and may predict the latter.

Adipokines and insulin have been shown to interplay with CRF [29]. According to a recent study [40], adolescents diagnosed with obesity and type 2 diabetes (T2DM) demonstrated significantly reduced CRF compared to those without T2DM. Additionally, Agostinis-Sobrinho and associates [28] observed an inverse association between serum adiponectin levels and CRF, among lean, but not overweight adolescents. It is well known 
that adiponectin has anti-atherogenic and anti-inflammatory properties [41], whereas on the other hand, leptin safeguards energy homeostasis by promoting weight loss and increasing energy output [42]. Subsequently, in the present study, as $\mathrm{VO}_{2 m a x}$ decreased among overweight children, an increment in leptin levels and a parallel decrease in circulating adiponectin concentrations were observed, triggering the production of more energy.

In accordance with the literature, the present, secondary analysis of previous data verified the existence of associations concerning leptin, adiponectin and hs-CRP with CRF, irrespective of the weight status categorization applied. Studies to date have shown that reduced CRF is associated with increased leptin [23-25] and reduced adiponectin [26,28] levels among children and adolescents. As far as hs-CRP is concerned, studies have verified the existence of a negative association between CRF and hsCRP as a marker of inflammation [43,44], CVD risk [45], and compromised liver function [46]. Additionally, hs-CRP has also been proposed as a prognostic factor of CRF among adults with systemic inflammation [44]. As far as dietary manipulations are concerned, randomized controlled trials (RCTs) have revealed that hs-CRP levels are reduced following a systematic moderate red wine intake [47], when adopting a Mediterranean dietary pattern [48], or energy restrictive diets, irrespective of their macronutrient composition $[49,50]$. On the other hand, based on observational data, higher hs-CRP concentrations are associated with lower diet quality and lower adherence to the Mediterranean diet [51].

With regard to the fibrinogen concentrations, in the present analysis it was shown that they have a good diagnostic ability for the prediction of $\mathrm{VO}_{2 \mathrm{max}}$. Lewitt and Baker [27] also revealed a negative relationship between fibrinogen levels and CRF among children and adolescents, indicating the initiation of a hypercoagulable state [52]. In parallel, fibrinogen has also been associated with hs-CRP in children with overweight and obesity [12]. In a follow-up study of approximately 2000 children [44], increased childhood fitness was associated with lower inflammation during the adult life and reduced fibrinogen in men. Thus, it appears that the interplay of CRF and fibrinogen during childhood might be an effector of adult CRF and coagulation status. Nutrition-wise, apart from obesity and increased body fat [53], observational studies have also associated elevated fibrinogen concentrations to greater iron, sugar, and caffeine intake [54], lower fiber content of the diet [55] and consumption of less than 1 kiwi weekly [56]. In parallel, clinical trials have revealed a reduction in fibrinogen levels following dietary protein restriction [57]. On the other hand, animal studies have revealed an elevation of fibrinogen levels, and the development of fibrin(ogen) deposits in the liver and white adipose tissue in mice, following a high-fat diet [58].

Taken et al. [59] showed that the pediatric exercise testing is imperative in assessing CVD risk. Moreover, according to a recent meta-analysis of longitudinal studies [60], early life CRF is associated with inverse outcomes concerning adult BMI, adiposity and metabolic syndrome. Obese children often demonstrate sleep apnea, dyspnea, several respiratory limitations and lung function abnormalities, leading to exercise intolerance [61]. CRF is an important contributor to the overall health, respiratory function and weight status of children. As reduced CRF is observed in children with obesity compared to their leaner counterparts [59], lung function is also compromised. According to the MINISTOP (Mobile-based INtervention Intended to STop Obesity in Preschoolers) trial [62], elevated body fat is associated with worse CRF, lower-body muscular strength and motor fitness among pre-schoolers. However, according to the literature [63-66], reduced CRF is due to impaired lung function only among children with increased adiposity, as a result of lung compliance. With CRF assessment being a difficult task in overweight children and in children with obesity, the use of easier methods predicting it in children is crucial. As such, simple assays including leptin, fibrinogen and hs-CRP levels might be able substitutes for the burdensome test performed on a cycle ergometer and may provide reliable data concerning CRF to the pediatric obesity management team. In Greece, during the previous decade, obesity rates have been soaring [67-70], with overweight children of increased severity demonstrating reduced physical activity levels [71]. According to Thivel and 
Aucouturier [14], assessment of CRF is an important clinical parameter for evaluating the functional health of children and is necessary during the implementation of obesity treatment interventions, in particular the ones based on physical activity. Thus, turning the spotlight on CRF assessment in pediatric obesity management, using assessments that are less difficult to perform, is important for proactive weight management.

Table 5 details the available evidence on the possible role of nutrition in improving CRF among children with obesity, provided by RCTs. Overall, the evidence suggest that exercise interventions appear superior to nutrition alone in improving CRF and reversing progress to diabetes by improving insulin sensitivity among children and adolescents with overweight/obesity. A long-term exercise program (6 months) is also efficient in reducing biomarkers of inflammation and improving endothelial dysfunction among adolescents with obesity [72]. In parallel, a lack of studies assessing nutrition interventions alone, without exercise, is apparent. For this, although nutrition is a known effector for the prevention of diabetes and obesity [73], with regard to the CRF, the need for incorporating exercise in the interventions is highlighted from the available primary evidence (Table 5) and recent meta-analyses [74].

Table 5. Existing parallel RCTs assessing exercise and nutrition interventions for improving CRF among children and adolescents with overweight/obesity.

\begin{tabular}{|c|c|c|c|c|c|c|}
\hline First Author & Study Origin & Participants & Intervention(s) & Comparator & $\begin{array}{c}\text { Intervention } \\
\text { Duration }\end{array}$ & Results \\
\hline Plavsic [75] & Serbia & $\begin{array}{l}\text { Adolescent girls } \\
\text { with obesity }(\mathrm{N}=44, \\
\text { aged } 13-19 \text { years })\end{array}$ & $\begin{array}{c}\text { Dietary advice on } \\
\text { CV biomarkers, } \\
\text { hormonal } \\
\text { parameters, and } \\
\text { cardiorespiratory } \\
\text { fitness and HIIT } \\
(n=22)\end{array}$ & $\begin{array}{l}\text { Dietary advice only } \\
\qquad(n=22)\end{array}$ & 12 weeks & $\begin{array}{l}\text { The intervention group increased } \\
\text { insulin sensitivity index and } \\
\text { workload and decreased glucose } \\
\text { AUC, insulin AUC, and hs-CRP } \\
\text { compared with the diet group. }\end{array}$ \\
\hline Ingul $[76,77]$ & Norway & $\begin{array}{l}\text { Children with } \\
\text { obesity } \\
(\mathrm{N}=99)\end{array}$ & $\begin{array}{l}\text { (1) HIIT }(n=33) \text {, } \\
\text { including } 4 \times 4 \mathrm{~min} \\
\text { bouts at } 85-95 \% \\
\text { HR }_{\max } 3 \\
\text { times } / \text { week and } \\
\text { nutrition advice } \\
\text { (2) MICS }(n=32), 44 \\
\text { min at } 60-70 \% \\
\text { HR }_{\max }, 3 \\
\text { times / week and } \\
\text { nutrition advice }\end{array}$ & $\begin{array}{c}\text { Nutrition advice } \\
\text { only } \\
(n=34)\end{array}$ & 12 weeks & $\begin{array}{l}\text { HIIT and MICS were equally } \\
\text { efficacious and superior to nutrition } \\
\text { alone, for improving LVS. HIIT was } \\
\text { effective in increasing CRF when } \\
\text { compared with the MICS and } \\
\text { nutrition interventions. }\end{array}$ \\
\hline Seo [78] & Korea & $\begin{array}{l}\text { Children and } \\
\text { adolescent with } \\
\text { moderate to severe } \\
\text { obesity }(\mathrm{N}=103)\end{array}$ & $\begin{array}{c}\text { Exercise } \\
\text { intervention } \\
\quad(n=32)\end{array}$ & $\begin{array}{c}\text { Usual care } \\
\text { (including nutrition } \\
\text { and exercise advice) } \\
\quad(n=71)\end{array}$ & 16 weeks & $\begin{array}{l}\text { Only the exercise group had a } \\
\text { significantly lower BMIz compared } \\
\text { to the baseline. Significant group by } \\
\text { time interaction was observed in } \\
\% \text { BF, LBM, DBP, hs-CRP and } \\
\text { wall-sit test. }\end{array}$ \\
\hline
\end{tabular}

\%BF, percent body fat; AUC, area under the curve; BMI, body mass index; BMIz, body mass index z-score; CRF, cardiorespiratory fitness; $\mathrm{CV}$, cardiovascular; DBP, diastolic blood pressure; HIIT, high-intensity interval training; hs-CRP, high-sensitivity C-reactive protein; $\mathrm{HR}_{\max }$, maximum heart rate; LBM, lean body mass; LVS, left ventricular peak systolic tissue velocity; MICS, moderate intensity continuous training; PWV, pulse wave velocity; RCT, randomized controlled trial; RT, resistance training.

Nevertheless, the CRF assessment entails several restrictions in daily clinical practice. Personnel with expertise is required, as well as suitable equipment. As a result, few pediatric clinics have units equipped for assessing the CRF. Children and adolescents with obesity often find it difficult to respond to the CPET as a result of emotional, psychological and behavioral disorders associated with obesity [79], complimented by the fact that they tend to avoid any kind of exercise. With the aid of hematological parameters and by taking the degree of obesity into consideration, exercise ability can be more easily defined [14].

A strong point in the present study was the favorable response of participants to the CPET, using the cycle ergometer. This could be due to the study design (informing the family, experienced personnel) but also to the method selection for the CRF assessment. In children, CPET using the cycle ergometer seems to outweigh that performed on the treadmill. Furthermore, an additional strong point in our study was the application of the $\mathrm{CPET}$ for assessment of the exercise ability and not only for defining the $\mathrm{VO}_{2 \max }$. 
Limitations of the present study include the relatively small sample used and the cross-sectional design and indirect definition of the body fat. BMI was selected as the most widely accepted method for indirect body fat assessment in children and adolescents. However, important aspects of the study herein include the assessment of $\mathrm{VO}_{2 \max }$ in a pediatric population, and its prediction by easy-to-perform assays.

Intervention studies have showed that diet and exercise consist of cost-effective strategies in improving metabolic profile among children with obesity, as well as among those with concomitant respiratory issues, and, as such, they could be employed to tamper the problem and mitigate the prevalence of type 2 diabetes mellitus in the young [80-83]. More research is required to assess the effect of nutrition interventions in improving CRF among children with overweight or obesity.

\section{Conclusions}

Childhood obesity is accompanied by too many comorbidities [84-86]. The present study verifies previous analyses [26] suggesting that in obese children, $\mathrm{VO}_{2 \max }$ can be predicted by hematological parameters (leptin and fibrinogen), bypassing more invasive methods. Early metabolic disorders due to childhood and adolescent obesity seem to affect cardiovascular fitness for exercise and their timely assessment is mandatory in order to protect children and adolescents with obesity from metabolic and cardiovascular complications, and reducing the risk for developing diabetes.

Author Contributions: Conceptualization, K.T.; methodology, K.T. and J.T.; data collection, K.T., K.K., E.H.; construction of the databases used in the analyses, K.T., A.V., and C.T.; formal analysis, K.T., J.T., C.T., M.G.G. and B.E.S.; writing-original draft preparation, K.T., M.G.G., and B.E.S.; writing-review and editing, K.T., E.H., J.T., K.K., A.V., M.G.G., and B.E.S.; supervision, J.T. and B.E.S. All authors have read and agreed to the published version of the manuscript.

Funding: This research received no external funding.

Institutional Review Board Statement: The study was conducted according to the guidelines of the Declaration of Helsinki and approved by the Bioethics Committee of the Medical School of Aristotle University of Thessaloniki (Ref No. 91/21-12-2009).

Informed Consent Statement: Informed consent was obtained from the parents/guardians of all participants involved in the study.

Data Availability Statement: Data are available upon request by the study's statistician (C.T.).

Conflicts of Interest: The authors declare no conflict of interest.

\section{References}

1. Reilly, S.M.; Saltiel, A.R. Adapting to obesity with adipose tissue inflammation. Nat. Rev. Endocrinol. 2017, 13, 633-643. [CrossRef]

2. Chooi, Y.C.; Ding, C.; Magkos, F. The epidemiology of obesity. Metabolism 2019, 92, 6-10. [CrossRef] [PubMed]

3. Pilcová, R.; Sulcová, J.; Hill, M.; Bláha, P.; Lisá, L. Leptin levels in obese children: Effects of gender, weight reduction and androgens. Physiol. Res. 2003, 52, 53-60. [PubMed]

4. Stylianou, C.; Tsinopoulou, G.A.; Farmakiotis, D.; Rousso, I.; Karamouzis, M.; Koliakos, G.; Arvanitakis, N.S. Ghrelin and leptin levels in obese adolescents. Relationship with body fat and insulin resistance. Hormones (Athens) 2007, 6, 295-303. [CrossRef] [PubMed]

5. Cambuli, V.M.; Musiu, M.C.; Incani, M.; Paderi, M.; Serpe, R.; Marras, V.; Cossu, E.; Cavallo, M.G.; Mariotti, S.; Loche, S.; et al Assessment of adiponectin and leptin as biomarkers of positive metabolic outcomes after lifestyle intervention in overweight and obese children. J. Clin. Endocrinol. Metab. 2008, 93, 3051-3057. [CrossRef]

6. Gajewska, J.; Kuryłowicz, A.; Mierzejewska, E.; Ambroszkiewicz, J.; Chełchowska, M.; Weker, H.; Kuźnicka, P.M. Complementary Effects of Genetic Variations in LEPR on Body Composition and Soluble Leptin Receptor Concentration after 3-Month Lifestyle Intervention in Prepubertal Obese Children. Nutrients 2016, 8, 328. [CrossRef]

7. Kannel, W.B.; Wolf, P.A.; Castelli, W.P.; Agostino, D.R.B. Fibrinogen and Risk of Cardiovascular Disease. JAMA 1987, $258,1183$. [CrossRef]

8. Bao, W.; Srinivasan, S.R.; Berenson, G.S. Plasma fibrinogen and its correlates in children from a biracial community: The Bogalusa Heart Study. Pediatr. Res. 1993, 33, 323-326. [CrossRef]

9. Tsinopoulou, G.A.; Grammatikopoulou, M.G.; Stylianou, C.; Emmanouilidou, E.; Kokka, P. Diabese youngsters have 3.7 more chances in developing metabolic syndrome compared with the obese. J. Endocrinol. Investig. 2010, 33, 549-553. [CrossRef] 
10. Danesh, J.; Collins, R.; Appleby, P.; Peto, R. Association of fibrinogen, C-reactive protein, albumin, or leukocyte count with coronary heart disease: Meta-analyses of prospective studies. JAMA 1998, 279, 1477-1482. [CrossRef]

11. Vilar, R.; Fish, R.J.; Casini, A.; Arbez, N.M. Fibrin(ogen) in human disease: Both friend and foe. Haematologica 2020, 105, $284-296$. [CrossRef] [PubMed]

12. Azevedo, W.F.; Cantalice, A.S.C.; Gonzaga, N.C.; da Simões, M.O.S.; Guimarães, A.L.V.; de Carvalho, D.F.; Medeiros, C.C.M. Fibrinogen: Cardiometabolic risk marker in obese or overweight children and adolescents. J. Pediatr. (Rio. J) 2015, 91, 464-470. [CrossRef] [PubMed]

13. Jiménez, V.M.; Estepa, R.M.; Camacho, R.M.M.; Estrada, R.C.; Luna, F.G.; Guitarte, F.B. Endothelial dysfunction is related to insulin resistance and inflammatory biomarker levels in obese prepubertal children. Eur. J. Endocrinol. 2007, 156, 497-502. [CrossRef]

14. Thivel, D.; Aucouturier, J. Cardiorespiratory Fitness Evaluation in Obese Youth. In The ECOG Free Obesity eBook; European Childhood Obesity Group, Ed.; European Childhood Obesity Group: Brussels, Belgium, 2015.

15. Watanabe, K.; Nakadomo, F.; Maeda, K. Relationship between body composition and cardiorespiratory fitness in Japanese junior high school boys and girls. Ann. Physiol. Anthropol. 1994, 13, 167-174. [CrossRef]

16. Freedson, P.; Goodman, T. Measurements of Oxygen Consumption. Pediatric Laboratory Exercise Testing. In Clinical Guide; Human Kinetics: Rowland, IL, USA, 1993.

17. Ortega, M.A.; Davis, L.C.; Barbeau, P.; Boyle, C.A. Oxygen uptake of overweight and obese children at different stages of a progressive treadmill test: Consumo de oxígeno de niños y niñas con sobrepeso y obesos en los diferentes estadios de una prueba progresiva en un tapiz rodante. Rev. Int. Cienc. Deporte 2010, 6, 74-90. [CrossRef]

18. Breithaupt, P.G.; Colley, R.C.; Adamo, K.B. Using the oxygen uptake efficiency slope as an indicator of cardiorespiratory fitness in the obese pediatric population. Pediatr. Exerc. Sci. 2012, 24, 357-368. [CrossRef] [PubMed]

19. Siconolfi, S.F.; Lasater, T.M.; McKinlay, S.; Boggia, P.; Carleton, R.A. Physical fitness and blood pressure: The role of age. Am. J. Epidemiol. 1985, 122, 452-457. [CrossRef] [PubMed]

20. Hong, H.R.; Ha, C.D.; Kong, J.Y.; Lee, S.H.; Song, M.G.; Kang, H.S. Roles of physical activity and cardiorespiratory fitness on sex difference in insulin resistance in late elementary years. J. Exerc. Nutr. Biochem. 2014, 18, 361-369. [CrossRef]

21. Nyström, C.D.; Henriksson, P.; Vizcaíno, M.V.; Medrano, M.; Sanchez, C.C.; Palencia, A.N.M.; Löf, M.; Ruiz, J.R.; Labayen, I.; López, S.M.; et al. Does Cardiorespiratory Fitness Attenuate the Adverse Effects of Severe/Morbid Obesity on Cardiometabolic Risk and Insulin Resistance in Children? A Pooled Analysis. Diabetes Care 2017, 40, 1580-1587. [CrossRef]

22. Arenaza, L.; Medrano, M.; Amasene, M.; Vigil, R.B.; Díez, I.; Graña, M.; Tobalina, I.; Maiz, E.; Arteche, E.; Larrarte, E.; et al Prevention of diabetes in overweight/obese children through a family based intervention program including supervised exercise (PREDIKID project): Study protocol for a randomized controlled trial. Trials 2017, 18, 372. [CrossRef]

23. Pomerants, T.; Tillmann, V.; Karelson, K.; Jürimäe, J.; Jürimäe, T. Ghrelin response to acute aerobic exercise in boys at different stages of puberty. Horm. Metab. Res. 2006, 38, 752-757. [CrossRef] [PubMed]

24. Gomez, M.D.; Eisenmann, J.C.; Martinez, G.S.; Veses, A.; Romeo, J.; Veiga, O.L.; Marcos, A.; AFINOS Study Group. Associations of physical activity and fitness with adipocytokines in adolescents: The AFINOS Study. Nutr. Metab. Cardiovasc. Dis. 2012, 22, 252-259. [CrossRef]

25. Pavón, J.D.; Ortega, F.B.; Artero, E.G.; Labayen, I.; Rodriguez, V.G.; Huybrechts, I.; Moreno, L.A.; Manios, Y.; Béghin, L.; Polito, A.; et al. Physical Activity, Fitness, and Serum Leptin Concentrations in Adolescents. J. Pediatr. 2012, 160, 598-603.e2. [CrossRef]

26. Tsiroukidou, K.; Papagianni, M.; Hatziagorou, E.; Tsinopoulou, G.A.; Giannopoulos, A.; Tsanakas, I. Exercise testing and adipokine levels for the evaluation of overweight and obesity in children. Hippokratia 2018, 21, 124-129.

27. Lewitt, M.S.; Baker, J.S. Relationship between abdominal adiposity, cardiovascular fitness, and biomarkers of cardiovascular risk in British adolescents. J. Sport Heal. Sci. 2020, 9, 634-644. [CrossRef]

28. Sobrinho, A.C.; Moreira, C.; Abreu, S.; Lopes, L.; Oliveira-Santos, J.; Johannessen, S.J.; Mota, J.; Santos, R. Serum Adiponectin Levels and Cardiorespiratory Fitness in Normoverweight and Overweight Portuguese Adolescents: The LabMed Physical Activity Study. Pediatr. Exerc. Sci. 2017, 29, 237-244. [CrossRef]

29. Hermoso, G.A.; Ceballos, C.R.J.M.; Aro, P.C.E.; Hackney, A.C.; Mota, J.; Vélez, R.R. Exercise, adipokines and pediatric obesity: A meta-analysis of randomized controlled trials. Int. J. Obes. 2017, 41, 475-482. [CrossRef] [PubMed]

30. Butte, N.F.; Garza, C.; de Onis, M. Evaluation of the Feasibility of International Growth Standards for School-Aged Children and Adolescents. J. Nutr. 2007, 137, 153-157. [CrossRef]

31. de Onis, M.; Onyango, A.W.; Borghi, E.; Siyam, A.; Nishida, C.; Siekmann, J. Development of a WHO growth reference for school-aged children and adolescents. Bull. World Health Organ. 2007, 85, 660-667. [CrossRef] [PubMed]

32. World Health Organization WHO Anthro for personal computers v 3.2.2. In Software for Assessing Growth and Development of the World's Children; WHO: Geneva, Switzerland, 2010.

33. de Onis, M.; Lobstein, T. Defining obesity risk status in the general childhood population: Which cut-offs should we use? Int. J. Pediatr. Obes. 2010, 5, 458-460. [CrossRef] [PubMed]

34. WHO Expert Consultaion Waist Circumference and Waist-Hip Ratio: Report of a WHO Expert Consultation; World Health Organization: Geneva, Switzerland, 2008; ISBN 9789241501491.

35. World Health Organization Who Step wise Approach to Surveillance (STEPS); WHO: Geneva, Switzerland, 2008.

36. Tanner, J.M. Growth and maturation during adolescence. Nutr. Rev. 1981, 39, 43-55. [CrossRef] 
37. Geffken, D.F.; Keating, F.G.; Cornell, E.S.; Bovill, E.G.; Tracy, R.P. The measurement of fibrinogen in population-based research: Studies on instrumentation and methodology. Arch. Pathol. Lab. Med. 1994, 118, 1106-1109. [PubMed]

38. Matthews, D.R.; Hosker, J.P.; Rudenski, A.S.; Naylor, B.A.; Treacher, D.F.; Turner, R.C. Homeostasis model assessment: Insulin resistance and beta-cell function from fasting plasma glucose and insulin concentrations in man. Diabetologia 1985, 28, 412-419. [CrossRef] [PubMed]

39. Tilaki, H.K. Receiver Operating Characteristic (ROC) Curve Analysis for Medical Diagnostic Test Evaluation. Casp. J. Intern. Med. 2013, 4, 627-635.

40. Bjornstad, P.; Truong, U.; Dorosz, J.L.; Green, C.M.; Baumgartner, A.; Coe, G.; Pyle, L.; Regensteiner, J.G.; Reusch, J.E.B.; Nadeau, K.J. Cardiopulmonary Dysfunction and Adiponectin in Adolescents with Type 2 Diabetes. J. Am. Heart Assoc. 2016, 5, 2804. [CrossRef]

41. Ouwens, D.M.; Bekaert, M.; Lapauw, B.; Van Nieuwenhove, Y.; Lehr, S.; Hartwig, S.; Calders, P.; Kaufman, J.M.; Sell, H.; Eckel, J.; et al. Chemerin as biomarker for insulin sensitivity in males without typical characteristics of metabolic syndrome. Arch. Physiol. Biochem. 2012, 118, 135-138. [CrossRef]

42. Trayhurn, P.; Beattie, J.H. Physiological role of adipose tissue: White adipose tissue as an endocrine and secretory organ. Proc. Nutr. Soc. 2001, 60, 329-339. [CrossRef] [PubMed]

43. Hermoso, G.A.; Sobrinho, A.C.; Mota, J.; Santos, R.M.; Bautista, C.J.E.; Vélez, R.R. Adiposity as a full mediator of the influence of cardiorespiratory fitness and inflammation in schoolchildren: The FUPRECOL Study. Nutr. Metab. Cardiovasc. Dis. 2017, 27, 525-533. [CrossRef]

44. Sun, C.; Magnussen, C.G.; Ponsonby, A.L.; Schmidt, M.D.; Carlin, J.B.; Huynh, Q.; Venn, A.J.; Dwyer, T. The contribution of childhood cardiorespiratory fitness and adiposity to inflammation in young adults. Obesity 2014, 22, 2598-2605. [CrossRef]

45. Ford, E.S. National Health and Nutrition Examination Survey C-Reactive Protein Concentration and Cardiovascular Disease Risk Factors in Children. Circulation 2003, 108, 1053-1058. [CrossRef]

46. Martins, C.; Freitas, I.; Pizarro, A.; Aires, L.; Silva, G.; Santos, M.P.; Mota, J. Cardiorespiratory fitness, but not central obesity or C-reactive protein, is related to liver function in obese children. Pediatr. Exerc. Sci. 2013, 25, 3-11. [CrossRef] [PubMed]

47. Estruch, R.; Sacanella, E.; Badia, E.; Antúnez, E.; Nicolás, J.M.; Solá, F.J.; Rotilio, D.; de Gaetano, G.; Rubin, E.; Márquez, U.A Different effects of red wine and gin consumption on inflammatory biomarkers of atherosclerosis: A prospective randomized crossover trial. Effects of wine on inflammatory markers. Atherosclerosis 2004, 175, 117-123. [CrossRef] [PubMed]

48. Esposito, K.; Marfella, R.; Ciotola, M.; Di Palo, C.; Giugliano, F.; Giugliano, G.; Armiento, D.M.; Andrea, D.F.; Giugliano, D. Effect of a mediterranean-style diet on endothelial dysfunction and markers of vascular inflammation in the metabolic syndrome: $\mathrm{A}$ randomized trial. JAMA 2004, 292, 1440-1446. [CrossRef]

49. Nicklas, J.M.; Sacks, F.M.; Smith, S.R.; LeBoff, M.S.; Rood, J.C.; Bray, G.A.; Ridker, P.M. Effect of dietary composition of weight loss diets on high-sensitivity c-reactive protein: The Randomized POUNDS LOST trial. Obesity (Silver Spring) 2013, 21, 681-689. [CrossRef]

50. Azadbakht, L.; Izadi, V.; Surkan, P.J.; Esmaillzadeh, A. Effect of a High Protein Weight Loss Diet on Weight, High-Sensitivity C-Reactive Protein, and Cardiovascular Risk among Overweight and Obese Women: A Parallel Clinical Trial. Int. J. Endocrinol. 2013, 2013, 1-8. [CrossRef]

51. Chan, R.; Yu, B.; Leung, J.; Lee, J.S.W.; Woo, J. Association of dietary patterns with serum high-sensitivity C-reactive protein level in community-dwelling older adults. Clin. Nutr. ESPEN 2019, 31, 38-47. [CrossRef]

52. Khunger, J.M.; Kumar, N.; Punia, V.P.S.; Malhotra, M.K. Study of Prothrombotic Changes in Metabolic Syndrome. Indian J. Hematol. Blood Transfus. 2020, 36, 695-699. [CrossRef] [PubMed]

53. Nienaber, C.; Pieters, M.; Kruger, S.H.; Stonehouse, W.; Vorster, H.H. Overfatness, stunting and physical inactivity are determinants of plasminogen activator inhibitor-1activity, fibrinogen and thrombin-antithrombin complex in African adolescents. Blood Coagul. Fibrinolysis 2008, 19, 361-368. [CrossRef]

54. Miura, K.; Nakagawa, H.; Ueshima, H.; Okayama, A.; Saitoh, S.; Curb, J.D.; Rodriguez, B.L.; Sakata, K.; Okuda, N.; Yoshita, K.; et al. Dietary factors related to higher plasma fibrinogen levels of Japanese-Americans in Hawaii compared with Japanese in Japan. Arterioscler. Thromb. Vasc. Biol. 2006, 26, 1674-1679. [CrossRef]

55. Freitas, R.N.; Luben, R.; Wareham, N.J.; Khaw, K.-T. Relationship between plasma fibrinogen and fiber intake in the EPIC-Norfolk cohort. Eur. J. Clin. Nutr. 2012, 66, 443-451. [CrossRef]

56. Rodriguez, R.J.I.; Marcos, G.M.A.; Alonso, P.M.C.; Puigdomenech, E.; Pacheco, N.B.; Gallastegui, M.N.; de la Fuente, A. de la C.; Ilarduya, O.L.; Fernandez, M.J.A.; de Laso, C.A.; et al. Effects of kiwi consumption on plasma lipids, fibrinogen and insulin resistance in the context of a normal diet. Nutr. J. 2015, 14, 97. [CrossRef] [PubMed]

57. Giordano, M.; Feo, D.E.; Lucidi, P.; Depascale, E.; Giordano, G.; Cirillo, D.; Dardo, G.; Signorelli, S.S.; Castellino, P. Effects of Dietary Protein Restriction on Fibrinogen and Albumin Metabolism in Nephrotic Patients; Elsevier: Amsterdam, The Netherlands, 2001; Volume 60.

58. Kopec, A.K.; Abrahams, S.R.; Thornton, S.; Palumbo, J.S.; Mullins, E.S.; Divanovic, S.; Weiler, H.; Owens, A.P.; Mackman, N.; Goss, A.; et al. Thrombin promotes diet-induced obesity through fibrin-driven inflammation. J. Clin. Investig. 2017, 127, $3152-3166$. [CrossRef] [PubMed]

59. Takken, T.; Bongers, B.C.; van Brussel, M.; Haapala, E.A.; Hulzebos, E.H.J. Cardiopulmonary Exercise Testing in Pediatrics. Ann. Am. Thorac. Soc. 2017, 14, S123-S128. [CrossRef] 
60. Mintjens, S.; Menting, M.D.; Daams, J.G.; van Poppel, M.N.M.; Roseboom, T.J.; Gemke, R.J.B.J. Cardiorespiratory Fitness in Childhood and Adolescence Affects Future Cardiovascular Risk Factors: A Systematic Review of Longitudinal Studies. Sport Med. 2018, 48, 2577-2605. [CrossRef] [PubMed]

61. Ruangnapaa, K.; Sritippayawana, S.; Sanguanrungsirikulb, S.; Deerojanawonga, J.; Nuanchan, P. Exercise intolerance in obese children and adolescents. Asian Biomed. 2014, 8, 659-664. [CrossRef]

62. Henriksson, P.; Sanchez, C.C.; Leppänen, M.H.; Nyström, D.C.; Ortega, F.B.; Pomeroy, J.; Ruiz, J.R.; Löf, M. Associations of Fat Mass and Fat-Free Mass with Physical Fitness in 4-Year-Old Children: Results from the MINISTOP Trial. Nutrients 2016, 8, 473. [CrossRef]

63. Fung, T.T.; Arasaratnam, M.H.; Grodstein, F.; Katz, J.N.; Rosner, B.; Willett, W.C.; Feskanich, D. Soda consumption and risk of hip fractures in postmenopausal women in the Nurses' Health Study. Am. J. Clin. Nutr. 2014, 100, 953-958. [CrossRef] [PubMed]

64. Ferretti, A.; Giampiccolo, P.; Cavalli, A.; Emili, M.J.; Tantucci, C. Expiratory flow limitation and orthopnea in massively obese subjects. Chest 2001, 119, 1401-1408. [CrossRef]

65. Zerah, F.; Harf, A.; Perlemuter, L.; Lorino, H.; Lorino, A.M.; Atlan, G. Effects of obesity on respiratory resistance. Chest 1993, 103, 1470-1476. [CrossRef]

66. Ray, C.S.; Sue, D.Y.; Bray, G.; Hansen, J.E.; Wasserman, K. Effects of obesity on respiratory function. Am. Rev. Respir. Dis. 1983, 128, 501-506. [CrossRef]

67. Kotanidou, E.P.; Grammatikopoulou, M.G.; Spiliotis, B.E.; Gantenbein, K.C.; Tsigga, M.; Tsinopoulou, G.A. Ten-year obesity and overweight prevalence in Greek children: A systematic review and meta-analysis of 2001-2010 data. Hormones (Athens) 2013, 12, 537-549. [CrossRef] [PubMed]

68. Grammatikopoulou, M.G.; Poulimeneas, D.; Gounitsioti, I.S.; Gerothanasi, K.; Tsigga, M.; Kiranas, E.; ADONUT Study Group. Prevalence of simple and abdominal obesity in Greek adolescents: The ADONUT study. Clin. Obes. 2014, 4, 303-308. [PubMed]

69. Grammatikopoulou, M.G.; Theodoridis, X.; Chourdakis, M. International Aspects: Abdominal Obesity in Greece. In Nutrition in the Prevention and Treatment of Abdominal Obesity, 2nd ed.; Watson, R.R., Ed.; Elsevier Inc: Oxford, UK, 2018; ISBN 9780128137819.

70. Grammatikopoulou, M.G.; Gkiouras, K.; Daskalou, E.; Apostolidou, E.; Theodoridis, X.; Stylianou, C.; Tsinopoulou, G.A.; Tsigga, M.; Dardavessis, T.; Chourdakis, M. Growth, the Mediterranean diet and the buying power of adolescents in Greece. J. Pediatr. Endocrinol. Metab. 2018, 31, 773-780. [CrossRef]

71. Grammatikopoulou, M.G.; Chourdakis, M.; Gkiouras, K.; Roumeli, P.; Poulimeneas, D.; Apostolidou, E.; Chountalas, I.; Tirodimos, I.; Filippou, O.; Lagogianni, P.S.; et al. Edmonton obesity staging system among pediatric patients: A validation and obesogenic risk factor analysis. J. Endocrinol. Investig. 2018, 41, 947-957. [CrossRef] [PubMed]

72. Tenório, T.R.S.; Balagopal, P.B.; Andersen, L.B.; Dias, R.R.M.; Hill, J.O.; Prado, L.M.C.; Prado, W.L. Effect of Low- Versus High-Intensity Exercise Training on Biomarkers of Inflammation and Endothelial Dysfunction in Adolescents with Obesity: A 6-Month Randomized Exercise Intervention Study. Pediatr. Exerc. Sci. 2018, 30, 96-105. [CrossRef] [PubMed]

73. Livesey, G.; Taylor, R.; Livesey, H.F.; Buyken, A.E.; Jenkins, D.J.A.; Augustin, L.S.A.; Sievenpiper, J.L.; Barclay, A.W.; Liu, S.; Wolever, T.M.S.; et al. Dietary Glycemic Index and Load and the Risk of Type 2 Diabetes: Assessment of Causal Relations. Nutrients 2019, 11, 1436. [CrossRef]

74. Cao, M.; Quan, M.; Zhuang, J. Effect of High-Intensity Interval Training versus Moderate-Intensity Continuous Training on Cardiorespiratory Fitness in Children and Adolescents: A Meta-Analysis. Int. J. Environ. Res. Public Health 2019, 16, 1533. [CrossRef]

75. Pervanidou, P.; Bastaki, D.; Chouliaras, G.; Papanikolaou, K.; Gantenbein, K.C.; Chrousos, G. Internalizing and externalizing problems in obese children and adolescents: Associations with daily salivary cortisol concentrations. Hormones (Athens) 2015, 14, 623-631. [CrossRef]

76. Plavsic, L.; Knezevic, O.M.; Sovtic, A.; Minic, P.; Vukovic, R.; Mazibrada, I.; Stanojlovic, D.; Hrncic, D.; Markovic, A.R.; Macut, D. Effects of high-intensity interval training and nutrition advice on cardiometabolic markers and aerobic fitness in adolescent girls with obesity. Appl. Physiol. Nutr. Metab. 2020, 45, 294-300. [CrossRef]

77. Ingul, C.B.; Dias, K.A.; Tjonna, A.E.; Follestad, T.; Hosseini, M.S.; Timilsina, A.S.; Strand, H.S.M.; Ro, T.B.; Davies, P.S.W.; Cain, P.A.; et al. Effect of High Intensity Interval Training on Cardiac Function in Children with Obesity: A Randomised Controlled Trial. Prog. Cardiovasc. Dis. 2018, 61, 214-221. [CrossRef]

78. Seo, Y.-G.; Lim, H.; Kim, Y.M.; Ju, Y.-S.; Lee, H.-J.; Jang, H.B.; Park, S.I.; Park, K.H. The Effect of a Multidisciplinary Lifestyle Intervention on Obesity Status, Body Composition, Physical Fitness, and Cardiometabolic Risk Markers in Children and Adolescents with Obesity. Nutrients. 2019, 11, 137. [CrossRef] [PubMed]

79. Dias, K.A.; Ingul, C.B.; Tjønna, A.E.; Keating, S.E.; Gomersall, S.R.; Follestad, T.; Hosseini, M.S.; Strand, H.S.M.; Ro, T.B.; Haram, M.; et al. Effect of High-Intensity Interval Training on Fitness, Fat Mass and Cardiometabolic Biomarkers in Children with Obesity: A Randomised Controlled Trial. Sports Med. 2018, 48, 733-746. [CrossRef] [PubMed]

80. Di Genova, L.; Penta, L.; Biscarini, A.; Di Cara, G.; Esposito, S. Children with Obesity and Asthma: Which Are the Best Options for Their Management? Nutrients 2018, 10, 1634. [CrossRef]

81. Verduci, E.; Lassandro, C.; Giacchero, R.; Miniello, V.; Banderali, G.; Radaelli, G. Change in Metabolic Profile after 1-Year Nutritional-Behavioral Intervention in Obese Children. Nutrients 2015, 7, 10089-10099. [CrossRef] [PubMed]

82. Myers, J.; Kokkinos, P.; Nyelin, E. Physical Activity, Cardiorespiratory Fitness, and the Metabolic Syndrome. Nutrients 2019, 11, 1652. [CrossRef] 
83. García, L.N.; Hermoso, G.A.; Tobarra, M.M.; Fernández, D.A.; Cano, S.A.; Vizcaíno, M.V. Cardiorespiratory Fitness as a Mediator of the Influence of Diet on Obesity in Children. Nutrients 2018, 10, 358. [CrossRef] [PubMed]

84. Ibáñez, L.; Barouti, K.; Markantes, G.K.; Armeni, A.K.; Georgopoulos, N.A. Pediatric endocrinology: An overview of the last decade. Hormones 2018, 17, 439-449. [CrossRef]

85. Ozsu, E.; Yazıcıoğlu, B. Obese boys with low concentrations of high-density lipoprotein cholesterol are at greater risk of hepatosteatosis. Hormones 2019, 18, 477-484. [CrossRef]

86. Tzifi, F.; Fretzayas, A.; Chrousos, G.; Gantenbein, K.C. Non-alcoholic fatty liver infiltration in children: An underdiagnosed evolving disease. Hormones 2019, 18, 255-265. [CrossRef] 